\title{
Deformations of upper soil slopes of retaining structures and shores with violated reinforced concrete fastening in riverbed reservoirs in Belarus
}

\author{
Viktor Levkevich ${ }^{1}$, Aleksandr Buzuk², Ivan Kirvel ${ }^{3}$, Sergey Parfomuk ${ }^{4, *}$ \\ ${ }^{1}$ Belarusian National Technical University, Nezavisimosti 65, 220013 Minsk, Republic of Belarus, e-mail: eco2014@tut.by \\ ${ }^{2}$ University of Civil Protection of the Ministry for Emergency Situations of the Republic of Belarus, Mashinostroiteley 25, 220118 \\ Minsk, Republic of Belarus, e-mail: uk007@rambler.ru \\ ${ }^{3}$ Department of Environmental Analysis, Pomeranian University in Słupsk, Partyzantów 27, 76-200 Slupsk, Poland, e-mail: ivan. \\ kirvel@apsl.edu.pl \\ ${ }^{4}$ Brest State Technical University, Moskovskaya 267, 224017 Brest, Republic of Belarus, e-mail: parfom@mail.ru ( ${ }^{*}$ corresponding \\ author)
}

\begin{abstract}
The conditions of wind waves influence on the ground upper soil slopes of retaining structures and natural shores that are fixed in the form of reinforced concrete fastening with deformations are considered. The results of modeling the regime of intra-water currents and field surveys of artificial water bodies are shown. A criterion for assessing the stability of ground slopes and coastal slopes with reinforced concrete fastening with a broken structure is proposed and the conditions for its applicability are determined. Measures for engineering protection of the reservoir shores are proposed via using a criterion for the stability of fixed slopes $\Pi_{\mathrm{k}}$. It is assumed that at $\Pi_{\mathrm{k}} \geq 1$ the slope profile with fastening plates deformed during operation acquires the contour of the dynamic equilibrium profile adopted for the calculated type of soil as a result of the destruction of the slope by waves.
\end{abstract}

Key words: reservoir, shore protection structure, modeling, stability criterion

\section{Introduction}

The total length of shore protection structures and fixed slopes of dams with various types of fasteners on reservoirs in the Republic of Belarus is about 250 $\mathrm{km}$. The length of damaged and destroyed coastal protection structures according to field surveys conducted from 2007 to 2017 is estimated at $44 \%$ or $110 \mathrm{~km}$ (Kalinin 2005). Approximately the same ratio is observed in the reservoirs of Poland (Banach 2013; Kaczmarek et al. 2015), the Czech Republic (Spanilá 1994, 1996), as well as in other regions of Europe (Vladev 2001).

Significant periods of operation of reservoirs contribute to the wear and tear of fixed assets, so the state of shore protection structures that ensure stability and "conservation" the original state of the shore slope or dam is extremely important for the normal function- ing of the facility and reduce the risk of accidents.

One of the causes of emergency situations in reservoirs is a violation of the local stability of the pressure front, which results in damage to the seams, mechanical destruction of the surface of the plates for securing shore protection structures, etc., which in turn leads to an accident. Figure 1 shows typical damage of shore protection structures registered in reservoirs in Belarus.

Violation of the integrity and further destruction of the slopes fastening and shore slopes of reservoirs made of precast concrete slabs can occur according to three calculation schemes (Fig. 2). The calculated schemes of the destruction of shore protection structures obtained in laboratory conditions are characterized by the following indicators (Buzuk 2015):

$1^{\text {st }}$ - Full Supply Level (FSL) is located below the destroyed filling of seams between the plates; 

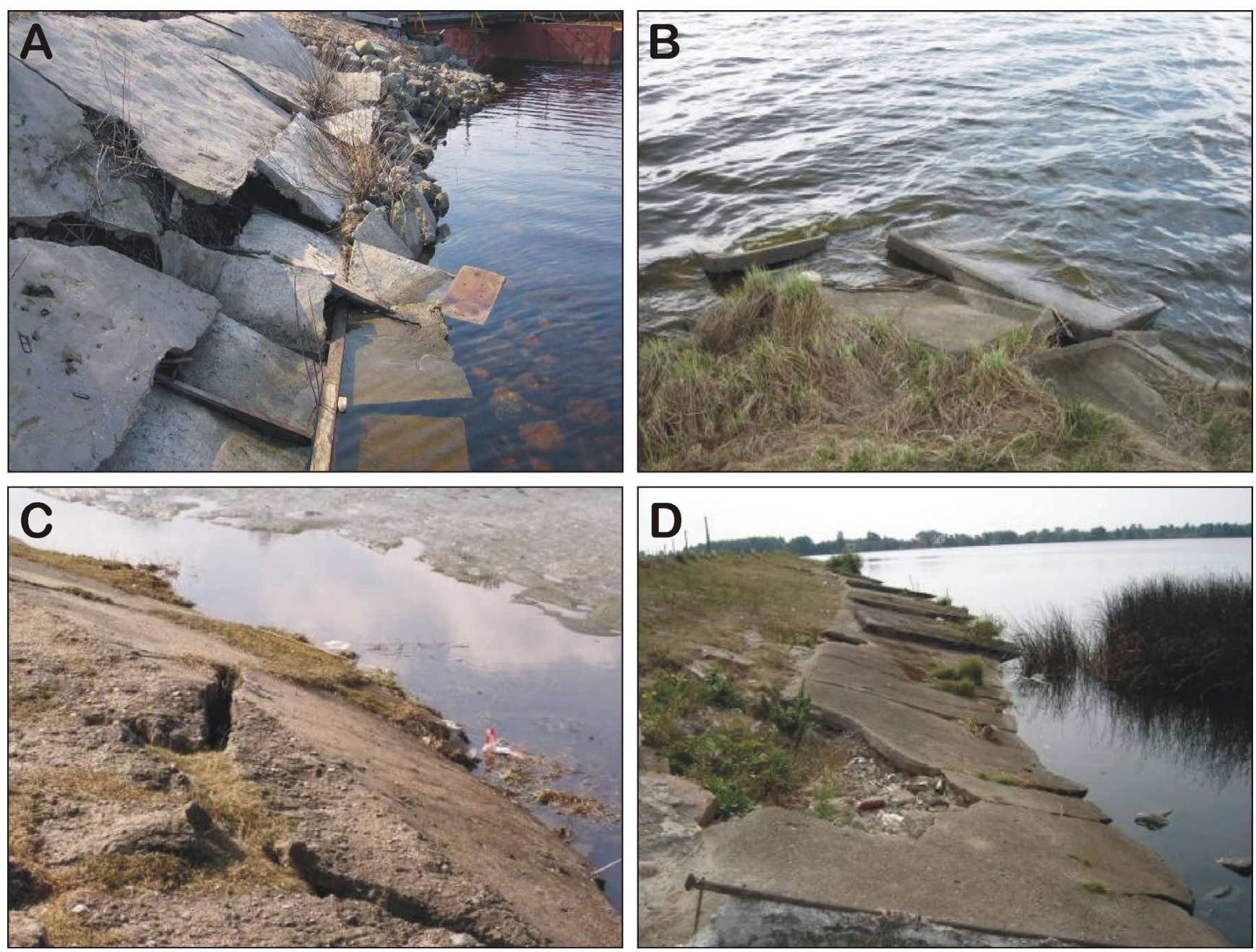

Fig. 1. Typical damage of shore protection structures in reservoirs: Lepelskoe (A), Volpa (B), Ostroshitsky Town (C), and Chigirinskoe (D)

$2^{\text {nd }}-$ FSL is located in the lower part of the plates with a destroyed filling of seams between the plates;

$3^{\text {rd }}-$ FSL is located in the upper part of the plates with a destroyed filling of seams between the plates.

\section{Initial Data}

A systematic analysis has shown that the causes of the shore state destruction include:

- insufficient accounting of the operating conditions of reservoirs in Belarus, associated with changes in the nature of regulation, which affects the water level regime and the wave regime (Buzuk 2015; Levkevich 2015);

- engineering calculations using integrated calculation schemes and dependencies which were designed for the marine environment and conditions for major reservoirs;
- inaccuracies in surveys combined with poor quality of construction and installation work;

- lack of proper technical supervision of construction quality;

- low level of operation and repair of structures (sealing seams, adding washouts, etc.);

- lack of a separate operational service and monitoring system for the state of waterworks.

The stability of shore protection structures of reservoirs is determined by hydrodynamic, hydrogeological, climatic, hydrometeorological, geomorphological, biological and other factors and conditions (Sapozhnikov and Levkevich 1977; Zolotarev 1955; Mikhnevich 1988; Buzuk 2015; Levkevich 2015).

The main factors that cause deformations of the anchorages of dams and the natural shores of water bodies include level, wind-wave and ice regimes, and the regime of currents and long-shore movement of 

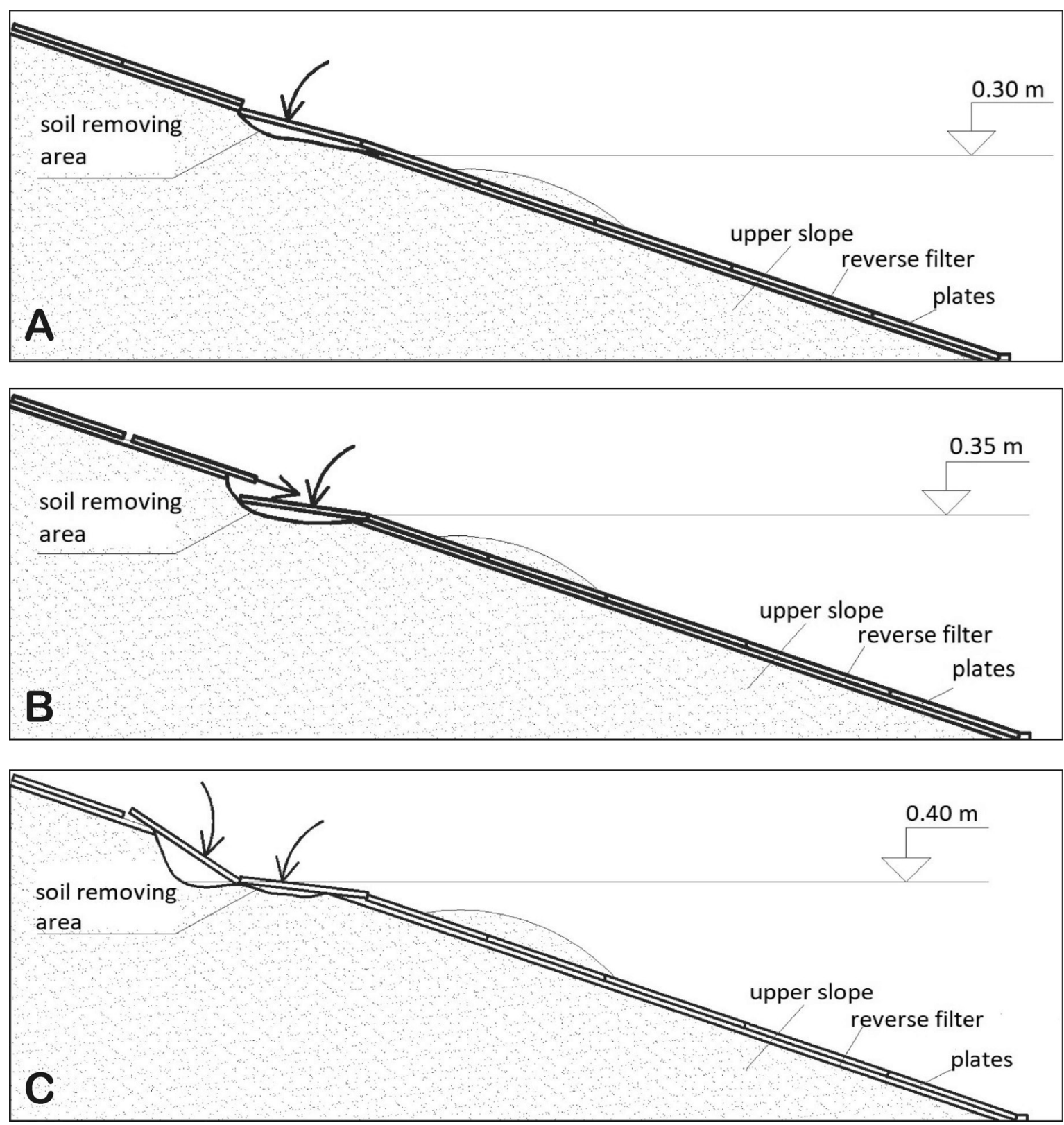

Fig. 2. Schemes of stability violation of the slope fastening: A - subsidence of the plate above the water line, B - subsidence of the plate above the water line and the sliding of the plate above it, $\mathrm{C}$ - crash of the plate above the water line and plate above it

sediments.

During the full-scale survey of the reservoir with shore protection structures were also conditions that affect the extent and intensity of deformation slopes: form and angle of laying of underwater and above-water parts of the slope and shore slope; the excess of the slope and the height of the coast above the FSL of the reservoir; the shape of the shoreline; the composition, structure, and physic-mechanical properties of soil; excessive moisture and suffusion processes, as well as the design of shore protection structures (Kondrat'ev 1951;
Zolotarev 1955; Sapozhnikov and Levkevich 1977; Mikhnevich 1988; Levkevich 2015).

\section{Results and Discussion}

To protect shores in Belarus, which depend on soil's nature, composing the slope and the reservoir's morphometric characteristics, the following shore clothing is used: breakwaters, intermittent fastening, and combined protection. Shore breakwaters are structures of trapezoidal cross-section designed to protect 
the shoreline from waves' eroding effect at a short distance from the water's edge. This type of shore protection structure was used at the Zaslavskoe Reservoir. In addition to shore breakwaters, a shore protection structure in the form of a transverse dam protruding deep into the reservoir with booms interrupting the longshore movement of sediment was used on the Pogost Reservoir to protect the shore from erosion (Shaitan 1962; Pyshkin 1973).

Intermittent shore fastening is an artificial analog of the coast shore: with small depths at protected areas (capes) and shoals in bays (Shaitan 1962; Pyshkin 1973; Levkevich 1979; Levkevich 1984). The combined protection of reservoir shores is widely used in Belarus. Local conditions determine the type of fastening: the composition of the soil composing the shore; morphometric indicators of the reservoir; the level of groundwater (Buzuk et al. 2011; Levkevich 2018). The Lepelskoe Reservoir is an example of using combined shore protection.

Given the purpose of breakwaters and intermittent shore anchoring, their use in reservoirs in Belarus is in most cases impractical due to the small size of the reservoirs, and at the same time, insignificant parameters of waves and the volume of sediment carried relative to large reservoirs and shores of the seas and oceans.

Combined protection is actively used at the Vitebsk HPP Reservoir that was commissioned in 2017 and the Polotsk HPP Reservoir in 2018 in the form of stone outline together with mesh mats made of ragged stone, reinforced concrete slabs covering together with a breakwater wall, stone outline together with a flattened slope, biological fastening together with mesh mats made of ragged stone. Figure 3 shows a view of
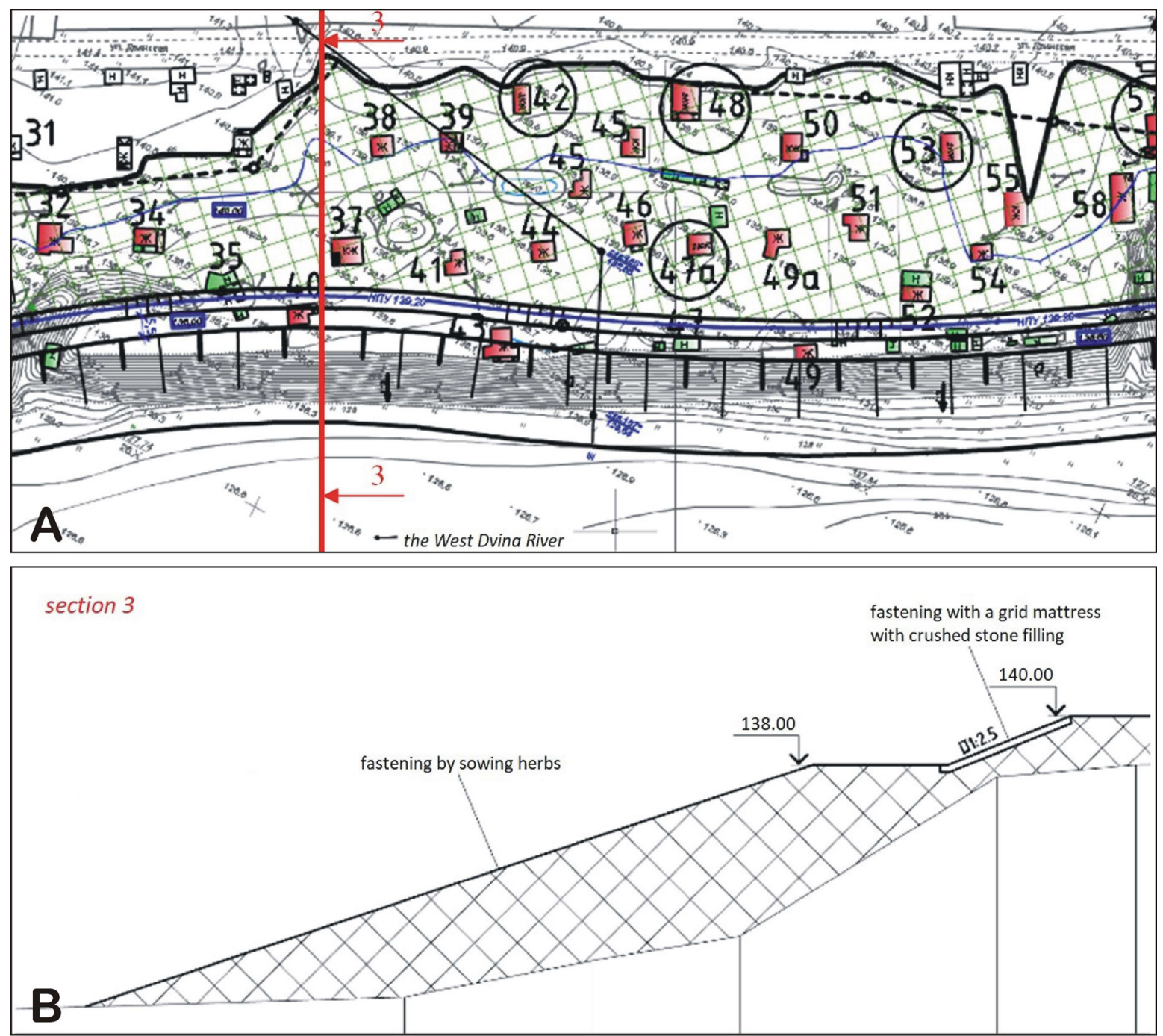

Fig. 3. Shore protection structure at the part of the Vitebsk HPP Reservoir: A - the part or the shore with combined protection, $\mathrm{B}$ - cut along the 3rd section of the shore 
the shore protection structure at the part of the Vitebsk HPP Reservoir at the Sudostroitel garden association that was chosen as the research object.

Constructing of these shore protection structures suggested a large volume of earthworks and demolition of buildings at the border of the FSL of the reservoir that would increase the time of its erection and cost of the overall project. Therefore, in order to reduce costs during the construction of the object, a simulation of the flow regime was carried out to assess the stability of the shore slopes.

\section{Modeling of the protection structure at the part of the Vitebsk HPP Reservoir at the Sudostroitel garden association}

When solving problems of modeling the velocity structure of intra-reservoir currents in water bodies that include reservoirs, an important role is played by determining the appropriate calculation schemes (algorithms), which can be used to calculate the distribution of the velocity field over the water area of the reservoir with an assessment of the stability of shore slopes and slopes of shore protection structures (Buzuk and Levkevich 2016).

Based on the data obtained as a result of previ- ously conducted field and laboratory studies, longitudinal velocity modeling was carried out on the basis of the code developed by A. Novikov in the integrated software development environment implemented in the TurboPascal language, which made it possible to calculate the values of the velocities and heads of the liquid flow.

Figure 4 shows data for calculating velocities and pressures for the reservoir's protected section, obtained by V. Levkevich (2018).

The presented simulation results are based on the developed simulation model that uses the convective diffusion process laws. The modeling of the intra-reservoir currents regime was based on the laws of water movement and impurities in reservoirs, taking into account possible resistance. The water movement is close to real conditions in the used software and includes changing the roughness in the stream's depth.

The two-dimensional mathematical model is used to describe the velocity structure of the liquid in the reservoir. It is obtained from the Navier-Stokes equation by integrating a three-dimensional problem of the $\mathrm{z}$-vertical coordinate, i.e., the reservoir's depth (Buzuk et al. 2011).

Ignoring the so-called rotary component of the

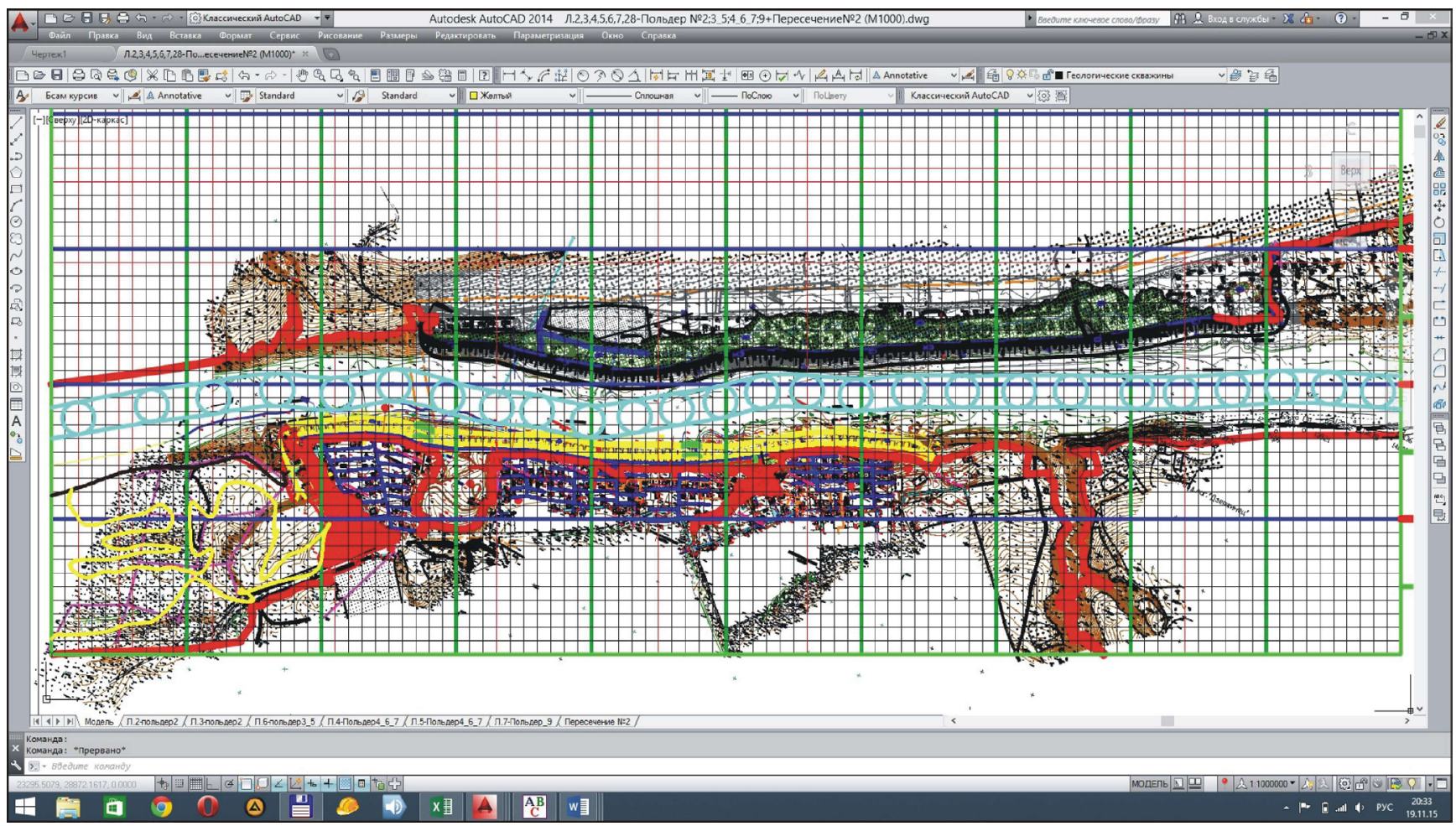

Fig. 4. Initial data for calculating velocities and pressures for the reservoir section of the Vitebsk HPP Reservoir (red lines - drainage zone; yellow line - shore protection near the village of Barvin; blue line - area of the coastal zone flooding; green sections - a polder with a protective dam) 
velocity flow was one of the assumptions in the simulation. It is important only when evaluating the process of convective diffusion of various impurities, which allowed reducing the solution of the problem to a Laplace equation:

$$
\nabla(F(x, y) \nabla P)=0 .
$$

The boundary conditions for equation 1 are immutability of the water cutoff; lack of filtration at a given difference in level marks at the input and output design gates for the simulated reservoir section. The numerical solution of problems based on equation 1 is effectively implemented by splitting by spatial factors, that is, by reducing interdependent one-dimensional problems to a low-critical solution. The coordinates of the shoreline contour, the depth of the reservoir, and the calculated ranges were set as the initial information on the coordinate grid.

Calculating the distribution of high-speed heads in the control lines of the reservoir section of the Vitebsk HPP Reservoir at the Sudostroitel garden is shown in Figure 5.

The destruction of the enclosing dam's upper slopes and the shores can be observed in adjacent areas to the water's edge of the highest saturation lines (maximum high-speed pressure, Fig. 5). The calculation of high-speed heads was carried out at the constant level of the reservoir's upper reaches for the project.

The results of flow modeling with consideration for the distribution over the calculated grid coordinates are shown in Table 1.

Table 1 shows that the estimated flow rates for not fastening sections of shore slopes exceed the maximum permissible values. These sections will be subject to deformation, which may lead to deviation from the shoreline's projected parameters. Besides, the values of flow velocities determined as a result of the calculation in conjunction with the bottom velocities within the boundaries of the old channel of the Western Dvina River may lead to deformations of the designed and constructed shore protection if the requirements of technical legal acts regulating their construction are not met.

When designing the shore protection structures of the Vitebsk HPP Reservoir, the convenience of its receipt, installation and subsequent operation, as well as the economic component, were taken into account. Comprehensive measures were proposed to protect the shore, including the joint use of stone outline and mesh mats made of ragged stone, stone outline, and flattened

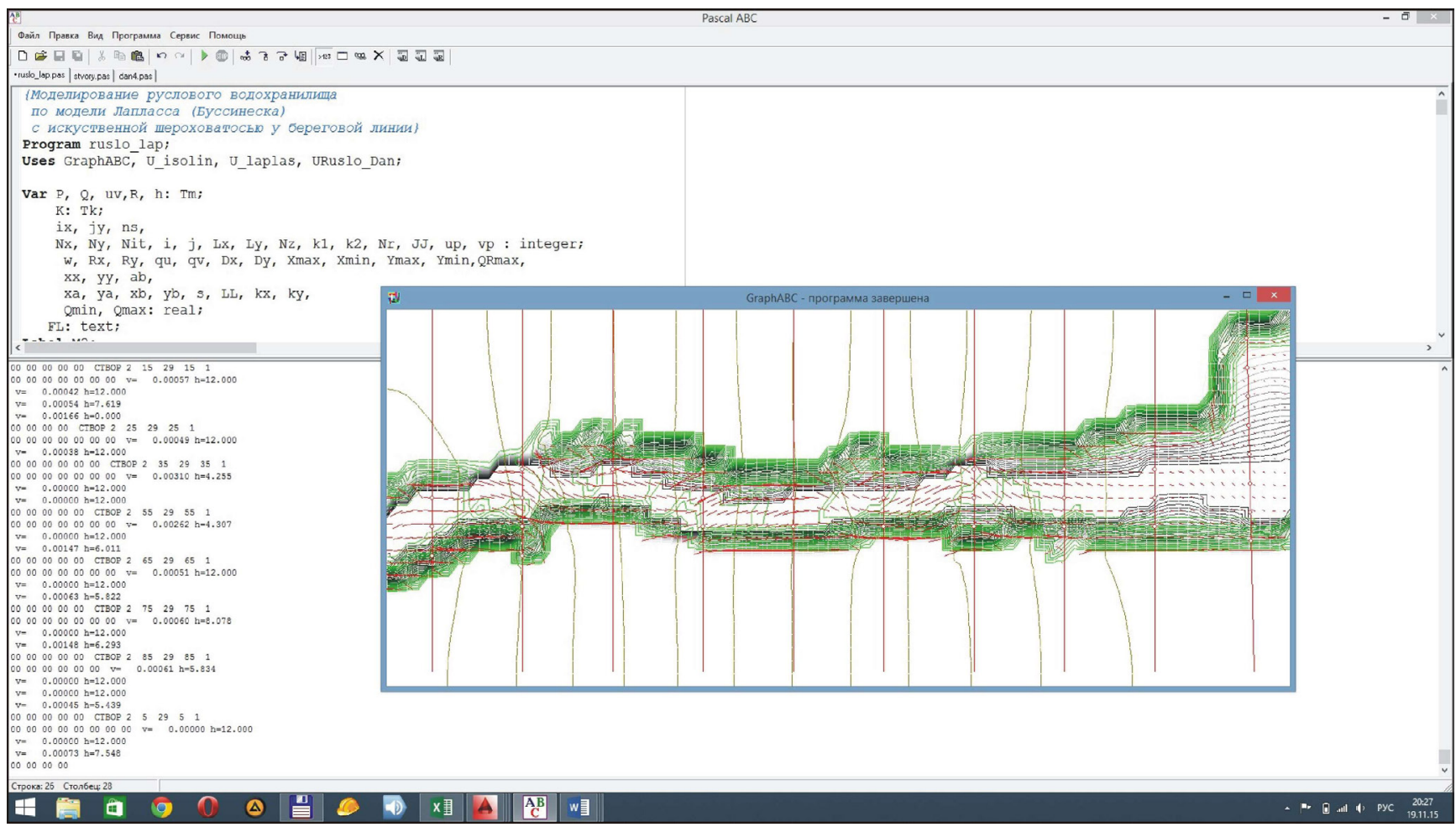

Fig. 5. Distribution of high-speed pressure on the reservoir section of the Vitebsk HPP Reservoir (gray lines - bottom relief; green lines - high-speed pressure; turquoise lines - places of maximum speeds; red lines - designed gates) 
Table 1. Results of the distribution of calculated velocities according to the coordinates of the calculated grid on the reservoir section

\begin{tabular}{ccc}
\hline Section No & Velocity $\mathbf{~}\left[\mathbf{m ~ s}^{-1}\right]$ & Coordinate in the grid node in the calculated alignment \\
\hline 1 & 0.73 & 7.6 \\
2 & $0.57 ; 0.42 ; 0.54 ; 1.66$ & $12.0 ; 12.0 ; 7.6 ; 0.0$ \\
3 & $0.49 ; 0.38$ & $12.0 ; 12.0$ \\
4 & $0.5 ; 0.4$ & $12.0 ; 12.0$ \\
5 & 3.1 & 4.3 \\
6 & $2.6 ; 1.5$ & $4.3 ; 6.0$ \\
7 & $0.51 ; 0.63$ & $12.0 ; 5.8$ \\
8 & $0.6 ; 1.48$ & $8.1 ; 6.3$ \\
9 & 0.61 & 5.8 \\
10 & $2.8 ; 1.34$ & $0.8 ; 3.7$ \\
\hline
\end{tabular}

slope (Fig. 6). Further, a forecast assessment of the scale of possible processing of slopes after shore protection measures was carried out. In the framework of the
“Technical proposals":

- forecast calculations of processing of the shoreline were performed;
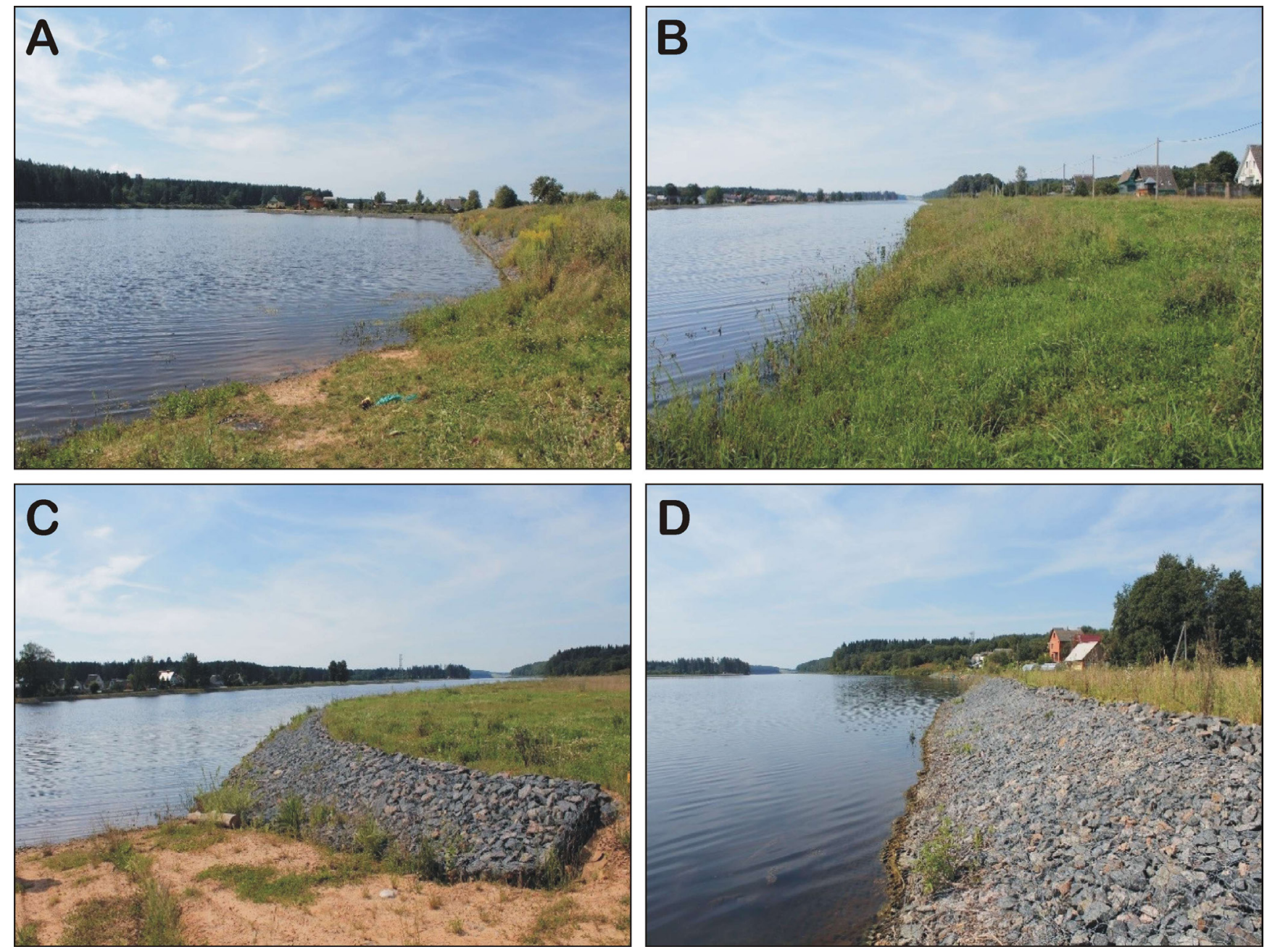

Fig. 6. Shore protection structures of the Vitebsk HPP Reservoir (combined protection): A - the beginning of the protected section, $\mathrm{B}$ - the middle part of the protected section; C-D - the ending of the protected section 


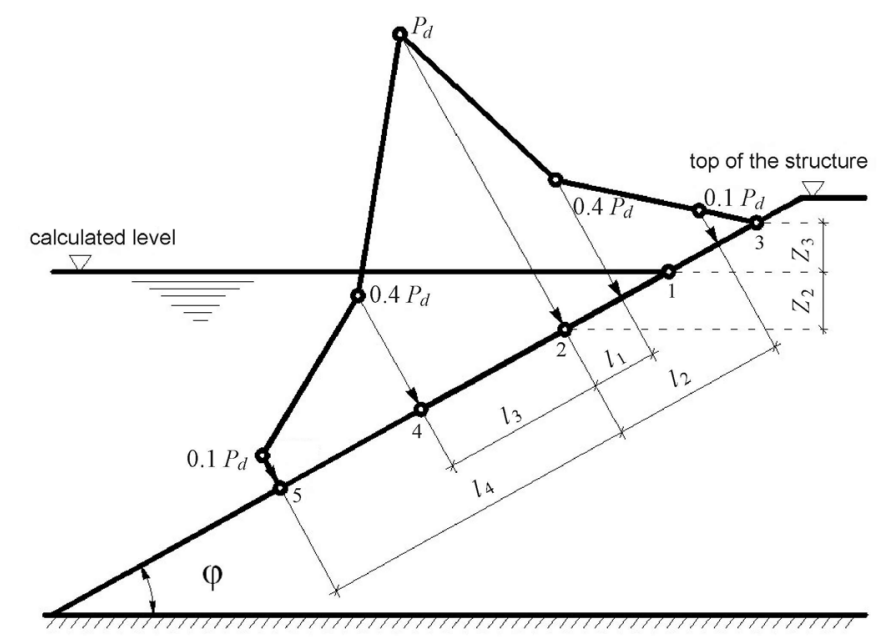

Fig. 7. Maximum wave pressure on the slope reinforced with slabs (Maksimchuk 1981)

- calculations of deformations of filled and planned slopes from the combined impact of wind waves, fluctuations in levels in the upstream, intra-water and long-shore currents and filtration flows were carried out;

- proposals of changing the slope fastening design were prepared.

It is established that sections of the coastline represented by enclosing shore protection dams and natural shores in the areas of the greatest impact and contact of the high-speed flow can be deformed. In accordance with (Chebotarev 1970; Levkevich 1971; Maksimchuk 1981), stability refers to the ability of a structure to maintain its functions, protective and load-bearing capabilities under the influence of external factors. Factors expressed in the form of loads and impacts that lead to the processing of the shoreline and deformation of structures anchorages and their distribution and combination should be taken into account to assess the sta- bility of slope anchorages shore protection structures.

The force of filtration pressure which exerts a weighing effect on the fixing plates and the slope surface due to a significant gradient of filtration pressure in the conditions of reservoirs in Belarus with limited linear dimensions, can be manifested exclusively only in the conditions of natural shores when the filtration front is unloaded on the slope. It causes the development of suffusion processes. When the filtration flow from the reservoir is infiltrated into the shore slope, then the effect of "pressing" the plate to the surface of the slope occurs (Levkevich 1971).

The scheme of the impact and distribution of wave pressure on the slope with a coating of reinforced concrete slabs is shown in Figure 7. The greatest loads occur on the slope at point 2 , corresponding to the wave capsizing zone. The nature of the velocity distribution in the wave flow during failure on the slope is displayed at Figure 8.

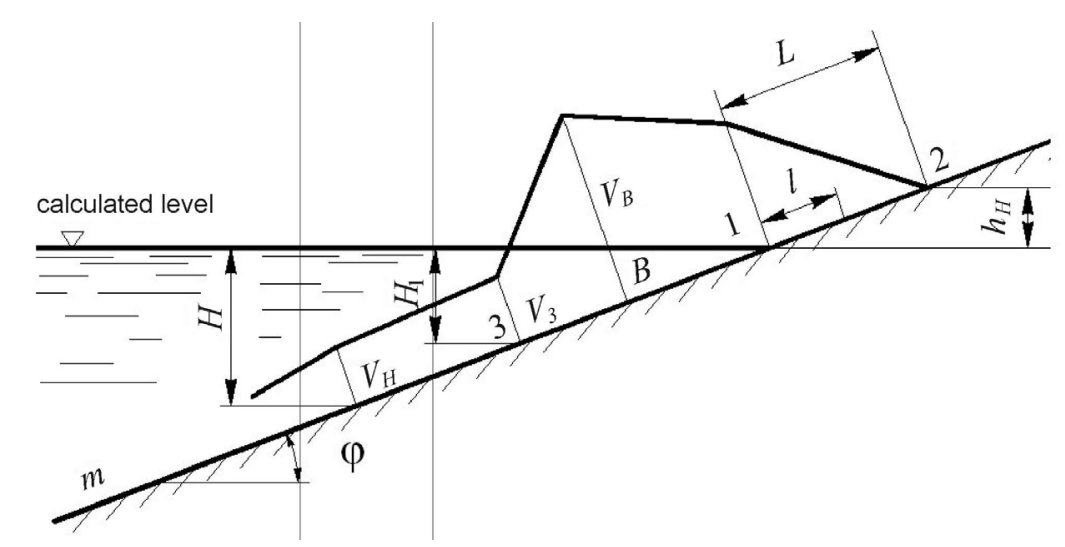

Fig. 8. Distribution of wave flow velocities along the slope (Maksimchuk 1981) 
The magnitude of the eroding velocity for the soil's training and structures is greater than the permitted erosion in the zone of destruction and overturning waves (Figs. 9-10). In the case of open seams, it causes the removal of soil from the space under plates located at levels close to FSL

The observed plate deformations in Belarus range from 3-5 to $10-30 \mathrm{~cm}$ with the height of possible wind waves up to $1.2 \mathrm{~m}$ (Levkevich 2015; Zolotarev 1955). When a hydrodynamic emergency occurs, then the estimated wave flow velocity at points 1,2 , and 3 (Fig. 8) for soil erosion can be determined by (Shaitan 1962):

$$
\begin{aligned}
& v_{1}=\frac{10 k_{r} \sqrt{g}}{2 \pi+m} \sqrt[6]{h^{2} \lambda} \\
& v_{1}=v_{1}\left(1-\frac{l}{h_{w} \sqrt{1+m^{2}}}\right) \\
& h_{w}=\frac{2 k_{r}}{m} h \sqrt[3]{\frac{\lambda}{h}} \\
& v_{3}=\frac{n \pi h}{\sqrt{\frac{\pi \lambda}{g} \operatorname{sh} \frac{4 \pi H_{1}}{\lambda}}} \\
& H_{1}=\frac{1.22}{m^{0.8}} \sqrt{h \lambda}
\end{aligned}
$$

where: $\mathrm{k}_{\mathrm{r}}$ - roughness coefficient equal to 0.9 for concrete slabs; $\mathrm{g}$ - gravity acceleration in $\mathrm{m} \mathrm{s}^{-2}$; $\mathrm{h}_{\mathrm{w}}$ - wave height in $\mathrm{m} ; \mathrm{m}$ - slope laying coefficient; $\mathrm{h}$ - height of the calculated $1 \%$ wave; $\lambda$ - wave lengthin $\mathrm{m}$.

\section{Stability of the slope in the conditions of wave action during wave rollback}

It is known that while the profile under deformations has not reached a dynamically stable shape, the processing material moves along its surface in the form of sediments, both along and across the water edge. It is also known that the stability of soil particles forming the underwater part of the shore profile (slope) is formed under the influence of hydrodynamic loads caused by wind waves, direct and reverse currents of the wave flow (Pyshkin 1973; Levkevich 1979; Levkevich 1984).

The occurrence of wave hydrodynamic pressure and the weighing pressure of the ground flow in the underlying layer is the main reason for the destruction of slopes located in the wave flow zone. Taking into account the ratio of forces acting on the soil element makes it possible to solve the applied problem of de- termining the stability criterion of the dynamic equilibrium profile.

The graphic-analytical methods based on round-cylindrical sliding surfaces, which reflect the stability of large soil massifs and do not consider the local stability of soil particles on the slope, are the most widely used of all the existing methods for calculating the stability of slopes of earth structures.

The existing dependencies for the permissible non-eroding velocities and the permissible (critical) entrainment force also do not take into account the influence of the hydrodynamic characteristics of the wave flow on the slope stability state. Therefore, the method of estimating the limit state of the slope was used to analyze the impact of a complex of forces acting on a soil element located on the surface of a coastal shoal in a wave flow. This method makes it possible to estimate the equilibrium profile's local stability based on account of the acting forces (Levkevich 1979, 1984, 2018).

Such an analysis approach allowed the authors to develop criteria for slope stability at different stages of slope deformations development (Levkevich 2018). In addition, E. Mikhnevich obtained a criterion for the stability of a slope with a stone fastening, and A. Buzuk obtained a criterion for the stability of a slope under a destroyed concrete fastening (Buzuk 2018). The structure of the scientifically based criteria obtained as a result of experimental field and laboratory studies is shown in Table 2.

At the stages of a stable slope formation (and it is the first 3-5 years after filling the reservoir) the value $\Pi_{1}$ is always less than 1 . At the final stage (approximately this period is about 10 years in Belarus's conditions), the shape of the slope equilibrium profile acquires a stable contour and the value $\Pi_{1} \geq 1$.

At the final stage (the stage of stabilization which is characterized by the attenuation of the deformation process over time) the development of the long-distance movement of the processing material along the water edge occurs. The slope stability criterion takes on a completely different form.

The conditions for stability of a ground slope covered with a reinforced concrete coating with a broken structure under the influence of a wave flow and the case of a wave rolling down a slope were considered (Fig. 11). The following forces act on the soil element located on the slope at an angle $\alpha$ to 


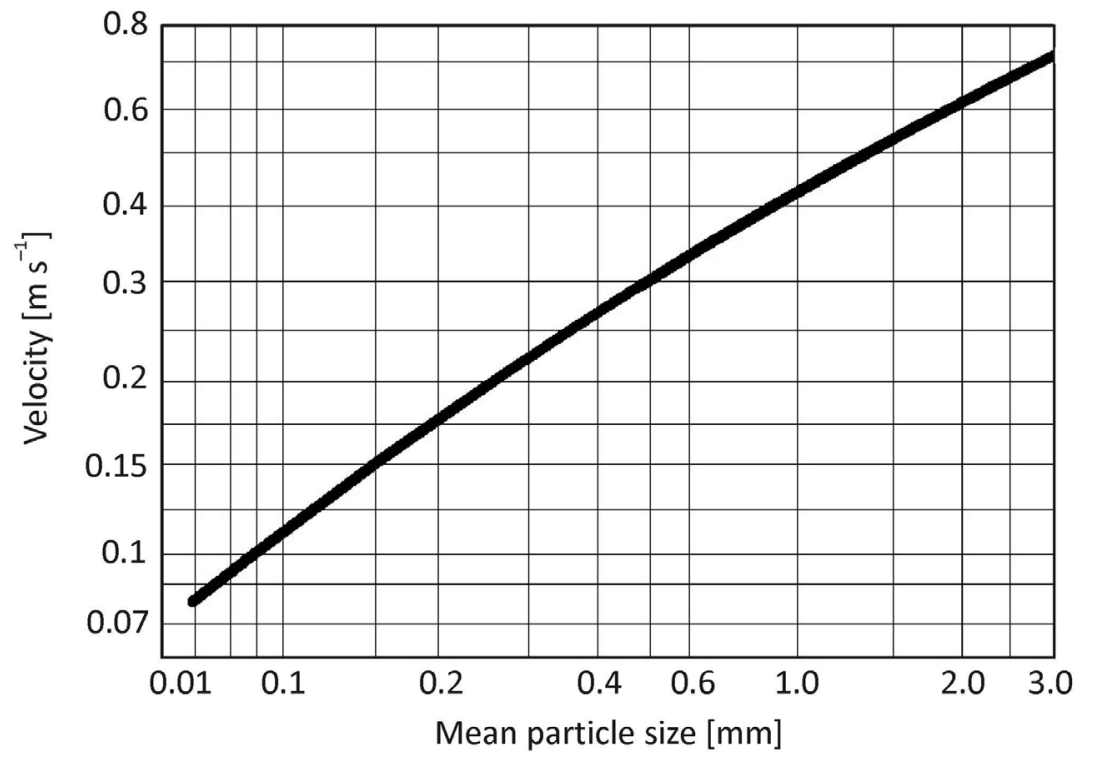

Fig. 9. Initial eroding wave velocity for disconnected soil (Mikhnevich 1988; Maksimchuk 1981; Buzuk 2018)

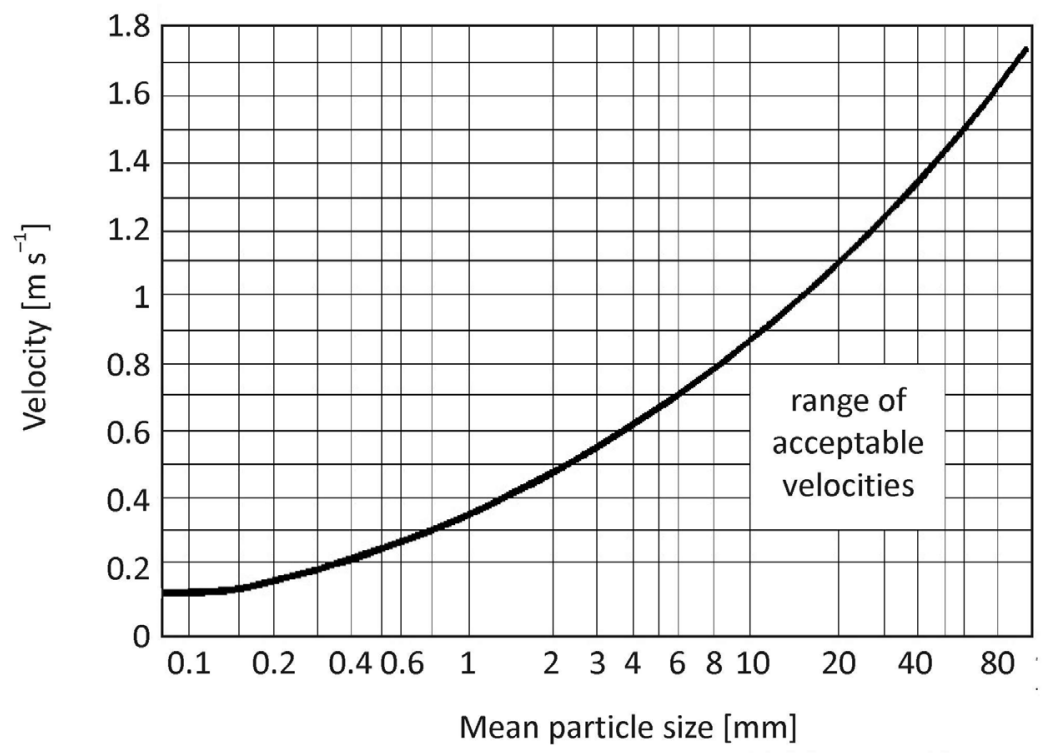

Fig. 10. Acceptable values of non-eroding bottom velocities (Mikhnevich 1988; Maksimchuk 1981; Buzuk 2018)

the horizon:

- $w \gamma_{\mathrm{s}}$ is gravity of the soil element, where $\mathrm{w}$ is the volume of the soil element, $\mathrm{m}^{3} ; \gamma_{\mathrm{s}}$ is the specific gravity of soil particles $\mathrm{N} \mathrm{m}^{-3}$;

- $\mathrm{Fa}_{\mathrm{oT}} \gamma_{\mathrm{w}} v^{2} / 2 \mathrm{~g}$ is the force created by the surface flow during the wave rollback, where $F$ is the area of the soil element, $\mathrm{m}^{2} ; \gamma_{\mathrm{w}}$ is the specific weight of water, $\mathrm{N} \mathrm{m}^{-3}$; $v$ is the velocity of the surface flow, $\mathrm{m} \mathrm{s}^{-1}$; $\mathrm{a}_{\text {oт }}$ is the coefficient of the velocity pressure impact on the soil element; $g$ is the gravity acceleration, $\mathrm{m} \mathrm{s}^{-2}$;
- $\quad F a \gamma_{w} h_{w}$ is the wave weighing force, where $h_{w}$ is the calculated wave height, $\mathrm{m}$; $\mathrm{a}$ is the coefficient of weighing wave pressure $\left(a=0.27\left(1-n_{s}\right)\right.$ for granular materials; $a=0.27$ for solid fastening; $n_{s}$ is the porosity of the soil on the slope);

- $\quad w \gamma_{s} \cos \alpha$ is the holding component of gravity, $\mathrm{N} \mathrm{m}^{-3}$;

- $\quad w \gamma_{s} \sin \alpha$ is the shear component of the gravity, $\mathrm{N} \mathrm{m}^{-3}$.

Equating the shear and component forces and taking into account the coefficient of internal 
Table 2. Stability criteria for upper slopes of dams from disconnected soils

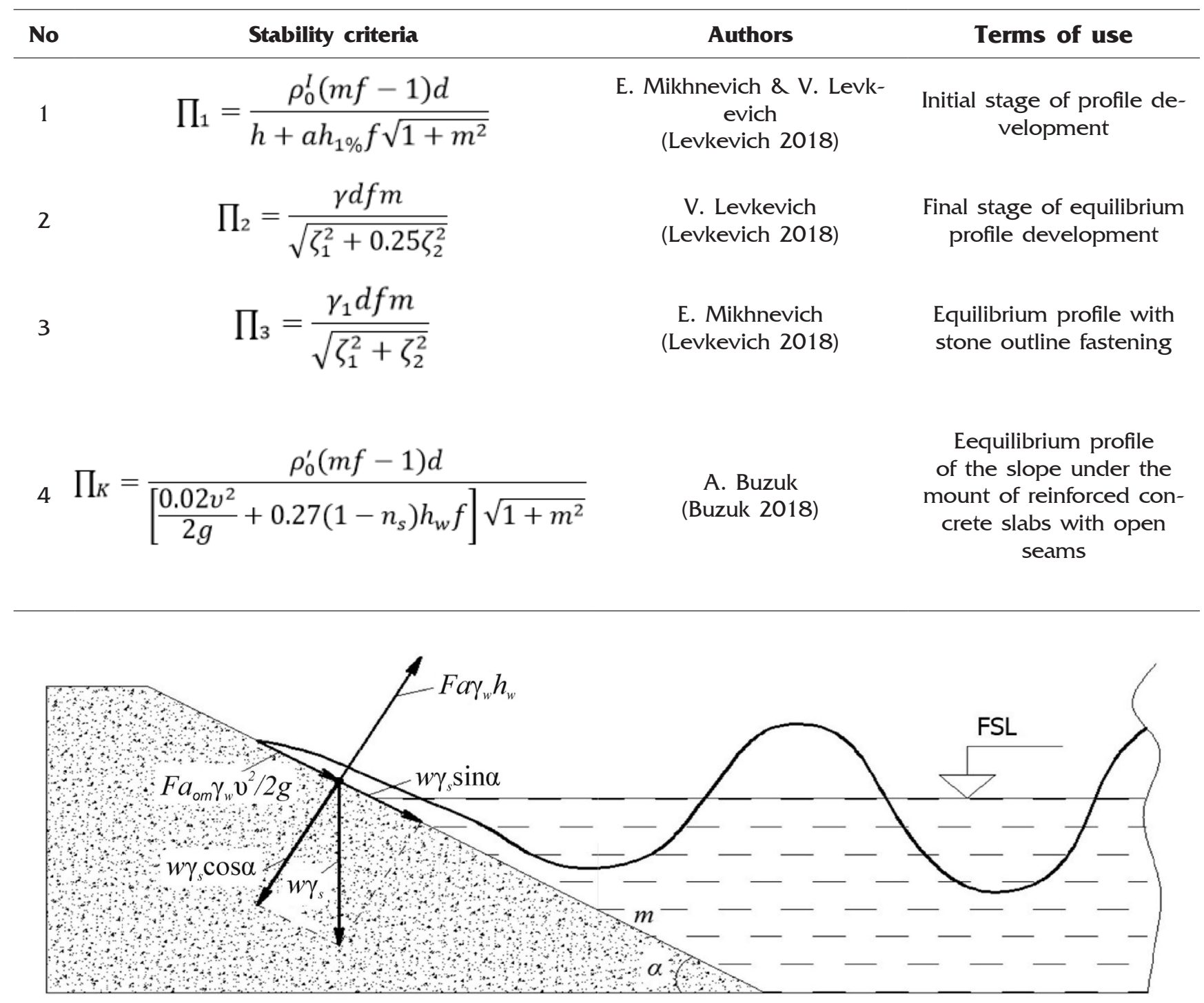

Fig. 11. Forces acting on the soil element on the slope during the wave rollback

friction of the soil $f$ the limit equilibrium equation was obtained in the following form:

$w \gamma_{s} \sin \alpha+\frac{F a_{\mathrm{o} m} \gamma_{w} v^{2}}{2 g}=\left(w \gamma_{s} \cos \alpha-F a \gamma_{w} h_{w}\right) f$.

Dividing the left and right sides of equation 7 by Fsina, it was obtained:

$d \gamma_{s}+\frac{a_{\mathrm{o} m} \gamma_{w} v^{2} \sqrt{1+m^{2}}}{2 g}+a \gamma_{w} h_{w} f \sqrt{1+m^{2}}=d \gamma_{s} m f$,

where: $\mathrm{d}=\mathrm{w} / \mathrm{F}$ is the diameter of the soil particles, $\mathrm{m} ; \mathrm{m}=\mathrm{ctg} \alpha$ is the slope laying coefficient.

Dividing equation 8 by $\operatorname{dg} \rho_{w}$, we get:

$$
\frac{\rho_{s}}{\rho_{w}}+\frac{a_{\mathrm{o} m} v^{2} \sqrt{1+m^{2}}}{2 g d}+\frac{a h_{w} f \sqrt{1+m^{2}}}{d}=\frac{\rho_{s} m f}{\rho_{w}},
$$

where: $\rho_{s}, \rho_{w}$ are the densities of soil and water particles, respectively, $\mathrm{kg} \mathrm{m}^{-3}$.

Denoting $\rho_{s} / \rho_{w}=\rho_{s}$ ' (relative density of soil particles) and multiplying equation 9 by $\mathrm{d}$, the equation took the form:

$$
\left(\frac{a_{\mathrm{o} m} v^{2}}{2 g}+a h_{w} f\right) \sqrt{1+m^{2}}=\rho_{s}^{\prime}(m f-1) d \text {. [10] }
$$

The ratio of the right to the left side of equation 10 is $\Pi_{\mathrm{K}}-$ a criterion for the stability of the slope (including fastening with plates), which has the following form for the average values of the coefficients $\mathrm{a}=0.27\left(1-\mathrm{n}_{\mathrm{s}}\right)$ and $\mathrm{a}_{\mathrm{OT}}=0.02$ :

$$
\Pi_{\kappa}=\frac{\rho_{s}^{\prime}(m f-1) d}{\left[\frac{0.02 v^{2}}{2 g}+0.27\left(1-n_{s}\right) h_{w} f\right] \sqrt{1+m^{2}}} .
$$


The stability of the slope is provided when the condition $\Pi_{\mathrm{K}} \geq 1$ is met, in which the shape of the slope with fastening plates with a broken structure acquires the contour of the dynamic equilibrium profile adopted for the calculated type of soil.

\section{Conclusions}

As a result of the analysis of deformations and failures of slope anchorages and studying the distribution of the removed material of the reverse filter, it was found that there are three schemes of loss of stability of shore protection structures for the reservoirs located on the territory of Belarus. The obtained schemes correspond to the stages of destruction of fasteners established due to many years of field and laboratory research.

Numerical modeling of the flow and shore currents distribution made possible: to provide fastening of shore slopes using the geological structure of the shores, soil characteristics and mode of operation of the Vitebsk HPP Reservoir; to choose optimal variant structures (from the point of view of sustainability and economic feasibility); and to get a positive economic effect (reduction of construction costs) by carrying out a complex of engineering shore protection measures.

Generalization of the experimental material allowed proposing a criterion for the stability of fixed slopes $\Pi_{\mathrm{K}}$. It is assumed that at $\Pi_{\mathrm{K}} \geq 1$ the slope profile with fastening plates deformed during operation acquires the contour of the dynamic equilibrium profile adopted for the calculated type of soil due to the destruction of the slope by waves. It is recommended to consider the stability criterion $\Pi_{\mathrm{K}}$ when assessing the stability of various types of shore protection of ground slopes of retaining structures and shore slopes.

\section{References}

Banach M., Kaczmarek H., Tyszkowski S., 2013, Rozwój osuwisk w strefie brzegowej sztucznych zbiorników wodnych na przykładzie osuwiska centralnego w Dobrzyniu nad Wisłą, Zbiornik Włocławski (Development of landslides in the shore zones of reservoirs, as exemplified by the central landslide at Dobrzyń-on-the-Vistula, Włocławek reservoir), Prz. Geogr. 85(3): 397-415 (in Polish, English summary).

Buzuk A.V., 2015, Rezul'taty laboratornykh issledovanii ustoichivosti beregoukrepitel'nykh sooruzhenii vo- dokhranilishch i ikh vliyanie na bezopasnoct' ob'ekta $\mathrm{v}$ chrezvychainykh situatsiakh (Results of laboratory studies of deformation of slopes with the coast protection structures of reservoirs and their impact on the safety in of emergency situations), Vestnik of the Institute for Command Engineers of the MES of the Republic of Belarus 22(2): 79-86 (in Russian).

Buzuk A.V., 2018, Kriterii ustoichivosti otkosov podpornykh sooruzhenii i beregov vodokhranilishch s deformirovannym zhelezobetonnym krepleniem (Stability criterion for the slopes of retaining structures and the banks of reservoirs with deformed reinforced concrete fasteners), Melioration 86(4): 24-30 (in Russian).

Buzuk A.V., Levkevich V.E., Novikov A.A., 2011, Matematicheskoe i gidravlicheskoe modelirovanie konvektivnoi diffuzii zagriaznenii $\mathrm{v}$ ruslovykh vodokhranilishchakh (Mathematical and hydraulic modeling of convective diffusion of contaminants in channel reservoirs), Proc. of the 9th International Scientific and Technical Conference. Vol. 3, Izd. BNTU, Minsk: 319 (in Russian).

Buzuk A.V., Levkevich V.E., 2016, Issledovanie ustoychivosti i effektivnosti raboty beregozashchitnykh sooruzhenii vodokhranilishch Belarusi $\mathrm{s}$ ispol'zovaniem materialov naturnykh nabliudenii, fizicheskogo i matematicheskogo modelirovania (Study of the sustainability and effectiveness of the coastal protection facilities of the reservoirs of Belarus using materials of field observations, physical and mathematical modeling), [in:] Aktual'nye voprosy ekonomiki stroitel'stva i gorodskogo khoziaistva (Current issues of construction economics and urban economy), Izd. BNTU, Minsk:112-126 (in Russian).

Chebotarev A.I., 1970, Gidrologicheskiy slovar' (Hydrological dictionary), Gidrometeoizdat, Leningrad, 306 pp (in Russian).

Kaczmarek H., Tyszkowski S., Banach M., 2015, Landslide development at the shores of a dam reservoir (Włocławek, Poland), based on 40 years of research, Environ. Earth Sci. 74: 4247-4259.

Kalinin M.Yu., 2005, Vodokhranilishcha Belarusi (Reservoirs of Belarus), Poligrafkombinat im. Ya. Kolasa, Minsk, 182 pp (in Russian).

Kondrat'ev N.E, 1951, Raschet vetrovogo volneniya i pereformirovanie beregov vodokhranilishch (Calculation of wind waves and reshaping of reservoir banks), Gidrometeoizdat, Leningrad, 107 pp (in Russian).

Levkevich E.M., 1971, Laboratornye issledovania pereformirovania neukreplennykh otkosov zemlianykh plotin pod vozdeistviem voln i filtratsionnykh sil (Laboratory studies of the reshaping of unreinforced slopes of earth dams under the influence of waves and filtration forces), Izv. VUZov 8: 98-102 (in Russian).

Levkevich E.M., 1979, Pererabotka beregov vodokhranilishch maloi GES (Processing of the shores of res- 
ervoirs of a small hydroelectric station), Leningrad: 226-227 (in Russian).

Levkevich V.E.,1984, Rekomendatsii po prognozirovaniyu pererabotki abrazionnykh beregov malykh ravninnykh vodokhranilishch, slozhennykh nesvyaznymi gruntami (Recommendations for predicting the processing of the abrasion banks of small plain reservoirs composed of loose soils), TsNIIKIVR, Minsk, 38 pp (in Russian).

Levkevich V.E., 2015, Dinamicheskaia ustoichivost' beregov vodokhranilishch Belarusi (Dynamic stability of the shores of reservoirs in Belarus), Izd. Pravo i ekonomika, Minsk, 305 pp (in Russian).

Levkevich V.E., 2018, Hydro-morphodynamika prybrezhnoi zony vodohranilishch GES Belarusi (Hydromorphodynamics of the shore zone of reservoirs of Hydroelectric Power Plants of Belarus), Izd. Pravo i ekonomika, Minsk, 139 pp (in Russian).

Maksimchuk V.L., 1981, Ratsional'noe ispol'zovanie i okhrana beregov vodokhranilishch (Rational use and protection of the shores of reservoirs), Izd. Budivelnik, Kiev, 112 pp (in Russian).

Mikhnevich E.I., 1988, Ustoychivost' rusl otkrytykh vodotokov (Stability of open watercourses), Uradgay, Minsk, 240 pp (in Russian).

Pyshkin B.A., 1973, Dinamika beregov vodokhranilishch (Dynamics of the waterside of reservoirs), Izd. Nauk. dumka, Kiev, 416 pp (in Russian).

Sapozhnikov G.P., Levkevich E.M, 1977, Iz opyta eksplu- atatsii kreplenii verkhovykh otkosov zemlanykh plotin i beregov vodokhranilishch BSSR (From the experience of operating the fastenings of the upper slopes of earthen dams and the banks of reservoirs of the BSSR), Vodnoe Khoziaistvo Belorussii 7: 97-105 (in Russian).

Shaitan V.S., 1962, Issledovanie vetrovykh voln na vodokhranilishche (Study of the wind waves in the reservoir), Trudy GL VODGEO 9: 19-57 (in Russian).

Spanilá T., 1994, effect of human activities on the abrasion and sliding progress at waterwork Nechranice, [in:] Oliveira R., Rodrigues L.F., Coelho A.G., Cunha A.P. (eds) Proc. of the 7th International Congress International Association of Engineering Geology. Vol. 4, A.A. Balkema, Rotterdam: 2687-2693.

Spanilá T., 1996, Landslides and abrasion processes on the shoreline in the water reservoir Nechranice, [in:] Senneset K. (ed.), Landslides/Glissements de terrain. Vol. 1. Proc. of the 7th International Symposium on Landslides, A.A. Balkema, Rotterdam: 579-583.

Vladev D., 2001, Hazardous geomorphologic processes in Gerlovsko Depression, Probl. Geogr. (Sofia) 1-2: 88-93

Zolotarev G., 1955, Ingenerno-geologicheskoe izuchenie beregovykh sklonov vodokhranilishch i otsenka ikh pererabotki (Engineering-geological study of the coastal slopes of reservoirs and assessment of their processing), Trudy LGGP AN SSSR 12: 188-235 (in Russian). 